International Journal of Agriculture, Environment and Bioresearch

Vol. 6, No. 01; 2021

ISSN: $2456-8643$

\title{
APPLICATION OF MICROBIAL FERTILIZER FROM LOCAL MICROORGANISM IN PAPRIKA CULTIVATION
}

\author{
Abdul Hasyim Sodiq ${ }^{1 *}$, Mieke R Setiawati ${ }^{2}$, Dwi Andreas Santosa ${ }^{3}$ and Dedi Widayat ${ }^{2}$ \\ ${ }^{1}$ Doctoral Program in Agricultural Sciences Padjadjaran University \\ ${ }^{2}$ Faculty of Agriculture Universitas Padjadjaran Jl. Raya Jatinangor Km.12 Sumedang \\ ${ }^{3}$ Department of Land Science and Land Resources, Faculty of Agriculture ,Bogor University Jl. Meranti, Ipb \\ Darmaga Bogor Campus, 16680
}

https://doi.org/10.35410/IJAEB.2021.5598

\begin{abstract}
This research was conducted to find out the ability of microbbiofertilizers from MOL in the cultivation of peppers. The design of the experiment used is a complete randomized design (RAL) of factorial patterns with two factors, the first factor is the use of biological fertilizers with six levels. The second factor is the use of anoganic fertilizer dose consisting of three levels. The highest crop height observation $(67,927 \mathrm{~cm})$ was indicated by the consortium's biofertilizer treatment with a $100 \%$ inorganic fertilizer dose (P4A1) while the largest stem base diameter $(12.09 \mathrm{~cm})$ was indicated by the treatment of bacillus cer isolate biofertilizer the origin of MOL rabbit manure with a dose of inorganic fertilizer $100 \%$ (P2A1) this remains consistent with the results of dry weight of plants with the best results shown by the treatment of biofertilizer isolate Bacillus Cereus with a dose of inorganic fertilizer $100 \%$ (P2A1). Furthermore, the highest total yield of peppers $(2,352 \mathrm{~g})$ was indicated by the treatment of consortium biofertilizer with $75 \%$ inorganic fertilizer (P4A2). The quality of the fruit observed in the harvest of 16 MST shows for the highest fruit volume $(341.11 \mathrm{ml})$ indicated by without the use of biofertilizer with a dose of inorganic fertilizer $100 \%$ (P0A1) and the thickness of the highest fruit $(7.47 \mathrm{~mm})$ indicated by the treatment of biofertilizer isolate Bacillus cereus from MOL bamboo root with a dose of inorganic fertilizer $100 \%$ (P1A1).
\end{abstract}

Keywords: Local Microorganime (MOL), Biofertilizer, Bacillus cereus 1, Bacillus cereus 2, Lysinibacillus sp.

\section{INTRODUCTION}

One of the vegetable commodities that is important to continue to develop is sweet chili (Paprika). Paprika is an agricultural commodity exported and consumed by almost all people in the world (Lancaster, 2009). Indonesia's paprika exports have been made to several countries in ASEAN and the Middle East. The growth in indonesia's export volume of fresh chili peppers and green peppers in 2012 was 23,477 tons, with an average growth of $27.23 \%$ year (Data Center and Agricultural Information System 2015). 
Vol. 6, No. 01; 2021

ISSN: $2456-8643$

One of the producing regions in west Java province is Cibodas village, paprika planting continues to be developed due to the increasing market needs, so that peppers have bright prospects to be cultivated (Prihmantoro and Indriani, 2003). In order to meet these needs, efforts need to be made to cultivate peppers intensively and commercially, so that the quantity, quality and contiunitas of production can also meet the standards of consumer demand (market). This can be done in various forms, for example by increasing fertilizer use, improving irrigation techniques, performing planting distance arrangements or using various superior microbs that can produce growing regulatory substances to increase plant growth and productivity.

Paprika farmers often use inorganic fertilizer (AB Mix) to increase their production. However, not all agricultural stores sell such fertilizers and have a relatively higher price than commonly used compound fertilizers. In line with Sesanti and Sismanto (2016), which stated that the scarcity of AB-mix inorganic fertilizers is generally due to self-produced by companies / farms engaged in hydroponics with a relatively more expensive selling price than compound fertilizers and liquid organics. Therefore, research is needed to find alternative fertilizers to reduce the use of inorganic fertilizers (AB-mix).

One way that can be taken to reduce or optimize the use of inorganic fertilizers is to use biofertilizer. Related to this in this study will try the application of 3 isolates resulting from insulation from MOL made by cibodas village farmers with combined the level of use of inorganic fertilizer doses on the cultivation of Paprika.

\section{Research Objectives}

1. How is the ability of Mikrob from MOL made by farmers from Cibodas Village Lembang District West Bandung Regency in improving the cultivation of peppers.

2. How is the ability of Mikrob from MOL made by farmers from Cibodas Village Lembang District Lembang West Bandung Regency in the efficiency of inorganic fertilizer on pepper cultivation.

\section{MATERIALS AND METHODS}

Research Place and Time

This research was conducted in January - May 2020 at Agronative Farmer Group Garden, Cibodas Village, West Bandung Regency. Laboratory analysis is conducted in the Lab. Land and AgroklimatUntirta, Lab. Soil Chemistry IPB, Lab of The Center for Conservation of Microorganisms BB-Biogen Ministry of Indonesia.

\section{Tools and Materials}

Selected isolates from MOL (3 isolates), 2 biological fertilizer comparison, Polybag capacity 5 $\mathrm{kg}$. Planting media (charcoal chaff, coconut schrub\&cassing), Temperature gauge and humidity of the room and other paprika production support equipment.

\section{Research Methods}

The design of the research experiment used is a complete randomized design (RAL) of factorial patterns with two factors, the first factor is the use of biological fertilizers with six levels. The second factor is the use of anoganic fertilizer dose consisting of three levels.

The first factor is the use of biofertilizer with six levels $(\mathrm{P})$ : 
$\mathrm{P} 0=$ No biofertilizer

$\mathrm{P} 1=$ Biofertilizer isolate 1 (Bacillus cereus 1$)$

$\mathrm{P} 2=$ Biofertilizer isolate 2 (Bacillus cereus 2)

P3 = Biofertilizer isolate 3 (Lysinibacillussp)

P4 = Biofertilizer Consortium Isolates 1, 2 and 3

P5 = Comparative biofertilizer 1 (Commercial Product)

P6 = Comparative biofertilizer 2 (Commercial Product)

The second factor is the dose of inorganic fertilizer consisting of three levels (A):

$\mathrm{A} 1=$ Inorganic fertilizer dose $100 \%$ of recommended dose.

A2 = Inorganic fertilizer dose $75 \%$ of recommended dose.

The combination of treatments as seen in the following table:

Table 1. Testing the Effectiveness of Biofertilizer for Improved Paprika Yield

\begin{tabular}{|lll|}
\hline BiofertilizerTreatments & \multicolumn{2}{l|}{ Dose of inorganic fertilizer } \\
\cline { 2 - 3 } & $\mathrm{A}_{1}$ & $\mathrm{~A}_{2}$ \\
\hline $\mathrm{P}_{0}$ & $\mathrm{P}_{0} \mathrm{~A}_{1}$ & $\mathrm{P}_{0} \mathrm{~A}_{2}$ \\
$\mathrm{P}_{1}$ & $\mathrm{P}_{1} \mathrm{~A}_{1}$ & $\mathrm{P}_{1} \mathrm{~A}_{2}$ \\
$\mathrm{P}_{2}$ & $\mathrm{P}_{2} \mathrm{~A}_{1}$ & $\mathrm{P}_{2} \mathrm{~A}_{2}$ \\
$\mathrm{P}_{3}$ & $\mathrm{P}_{3} \mathrm{~A}_{1}$ & $\mathrm{P}_{3} \mathrm{~A}_{2}$ \\
$\mathrm{P}_{4}$ & $\mathrm{P}_{4} \mathrm{~A}_{1}$ & $\mathrm{P}_{4} \mathrm{~A}_{2}$ \\
$\mathrm{P}_{5}$ & $\mathrm{P}_{5} \mathrm{~A}_{1}$ & $\mathrm{P}_{5} \mathrm{~A}_{2}$ \\
$\mathrm{P}$ & $\mathrm{P}_{6} \mathrm{~A}_{1}$ & $\mathrm{P}_{6} \mathrm{~A}_{2}$ \\
\hline
\end{tabular}


Each treatment will be planted on 4 units of polybag and repeated as many as 3 replays, resulting in 168 units of polybag treatment plant.

\section{RESULTS}

Plant change

The height of the plant is measured from the base of the stem to the highest end of the leaf, the high observation of the plant is carried out from 4 week after planting (WAP) to 6 WAP. Observations showed $100 \%$ inorganic fertilizer treatment still showed better results compared to $75 \%$ inorganic fertilizer use treatment. The data of the high observation of paprika plants can be more complete can be seen in the pictures and tables, the following:

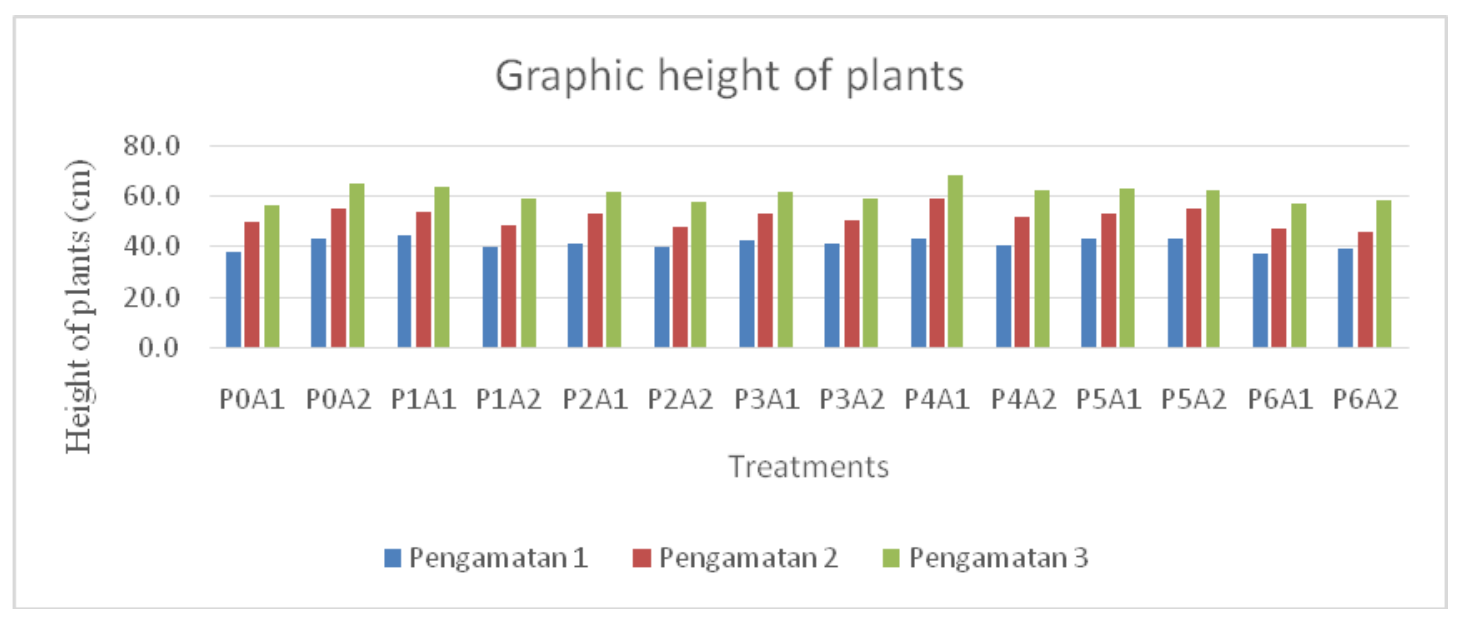

Figure 1. Plant High Observation Graph 4 - 6 WAP.

Table 2. Effect of Biofertilizer and Inorganic Fertilizer on Plant Height at 4 - 6 MST.

\begin{tabular}{|llll|}
\hline Treatment & \multicolumn{3}{l|}{ Observation $(\mathrm{cm})$} \\
\cline { 2 - 4 } & $1(4 \mathrm{WAP})$ & $2(5 \mathrm{WAP})$ & $3(6 \mathrm{WAP})$ \\
\hline P0A1 & $37.900 \mathrm{a}$ & $50.103 \mathrm{bcd}$ & $56.220 \mathrm{c}$ \\
P1A1 & $44.470 \mathrm{a}$ & $53.793 \mathrm{abc}$ & $63.780 \mathrm{abc}$ \\
P2A1 & $41.570 \mathrm{a}$ & $53.283 \mathrm{abcd}$ & $61.803 \mathrm{abc}$ \\
P3A1 & $42.887 \mathrm{a}$ & $52.810 \mathrm{abcd}$ & $61.897 \mathrm{abc}$ \\
P4A1 & $43.033 \mathrm{a}$ & $59.247 \mathrm{a}$ & $67.927 \mathrm{a}$ \\
P5A1 & $43.070 \mathrm{a}$ & $53.270 \mathrm{abcd}$ & $62.653 \mathrm{abc}$ \\
P6A1 & $37.503 \mathrm{a}$ & $47.020 \mathrm{~cd}$ & $57.367 \mathrm{bc}$ \\
\hline
\end{tabular}




\begin{tabular}{llll}
\hline P0A2 & $43.317 \mathrm{a}$ & $54.850 \mathrm{ab}$ & $64.877 \mathrm{ab}$ \\
P1A2 & $40.287 \mathrm{a}$ & $48.720 \mathrm{bcd}$ & $59.087 \mathrm{bc}$ \\
P2A2 & $40.137 \mathrm{a}$ & $48.143 \mathrm{bcd}$ & $57.793 \mathrm{bc}$ \\
P3A2 & $41.030 \mathrm{a}$ & $50.313 \mathrm{bcd}$ & $58.897 \mathrm{bc}$ \\
P4A2 & $40.527 \mathrm{a}$ & $52.010 \mathrm{abcd}$ & $62.153 \mathrm{abc}$ \\
P5A2 & $43.320 \mathrm{a}$ & $55.077 \mathrm{ab}$ & $62.597 \mathrm{abc}$ \\
P6A2 & $39.243 \mathrm{a}$ & $45.967 \mathrm{~d}$ & $58.547 \mathrm{bc}$
\end{tabular}

Description : The numbers followed by the same letter in one column show no real difference on the Duncan test at a real rate of 0.05 .

Duncan's test results of the microb isolate consortium (P4A1) caused the plant's height at 5 and 6 MST to be higher than without being given biofertilizer (Table 2). The application of a single isolate shows the height of the plant equals the consortium of microbs in the administration of $100 \%$ inorganic fertilizer. The reduction of the dose of inorganic fertilizer to $75 \%$ causes a single isolate plant of the same height as the control but the microb consortium can still exceed the height of the control plant and equal to the commercial comparison (P5A2). The high growth of plants both at inorganic doses of $100 \%$ and $75 \%$ can be seen in the following figure:

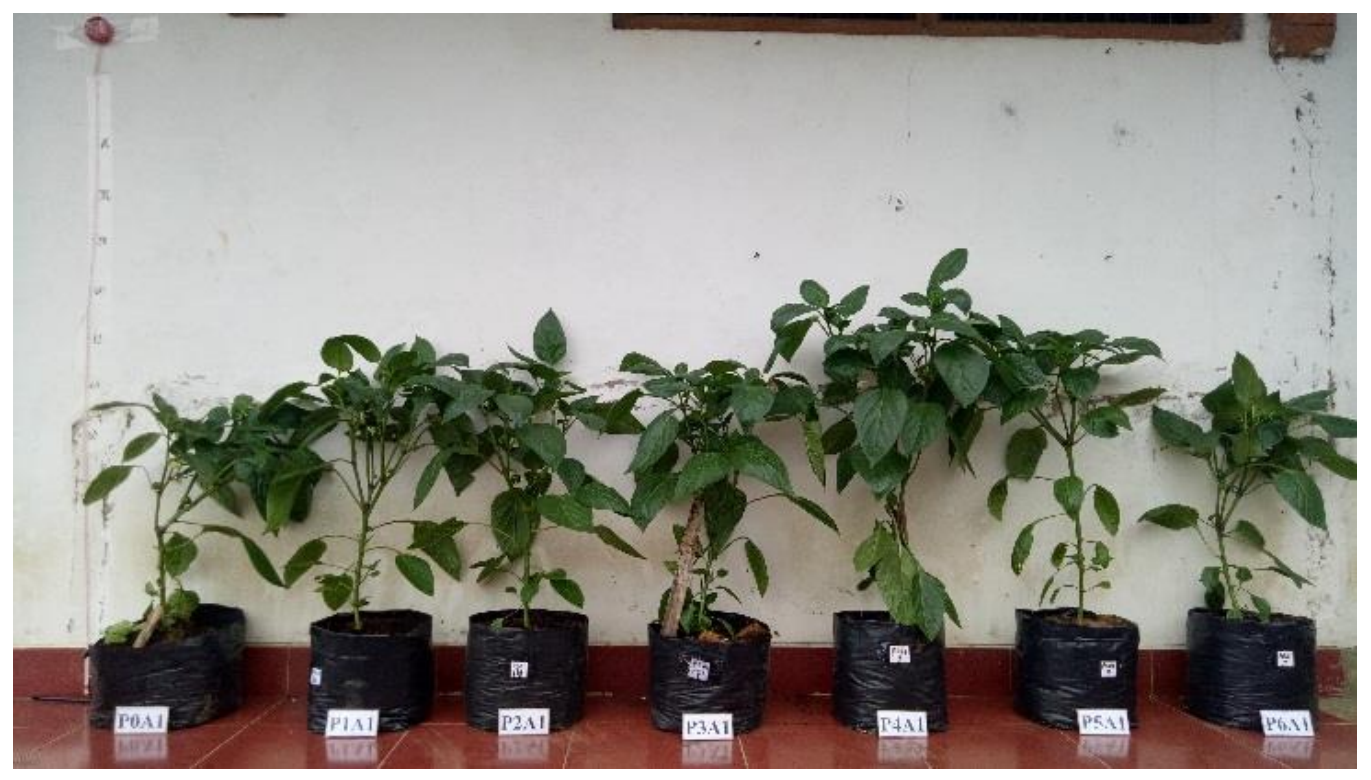

Figure 2. Comparison of The Use of Various Biofertilizers with 100\% inorganic doses at 6 WAP 


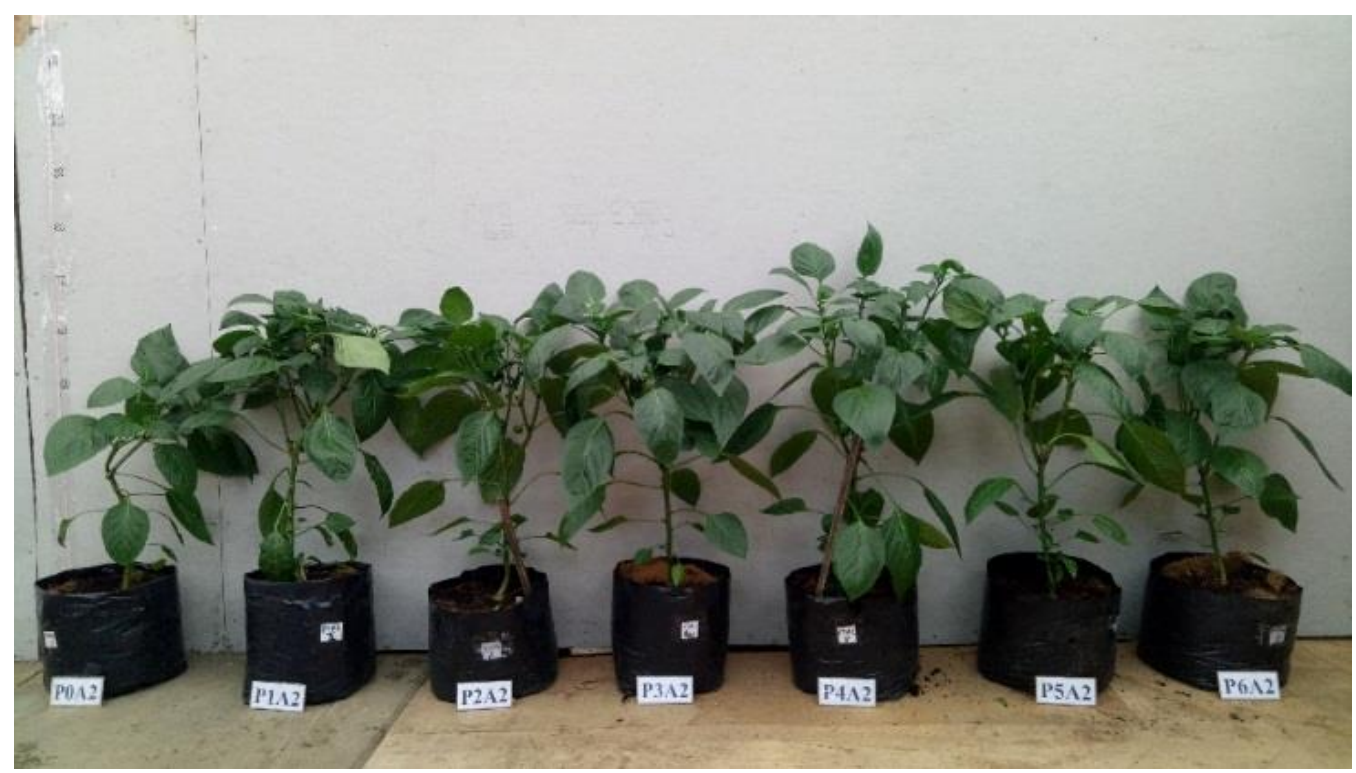

Figure 3. Comparison of The Use of Various Biofertilizers with inorganic doses $75 \%$ at 6 WAP

Observations of the diameter of the base of the stem are observed using a digital shove term performed at the base of the stem of the paprika plant. The observations showed p2a1 treatment on 3 observations always showed the best results although not significantly different from other treatments. This is still in line with the high observation results of plants where $100 \%$ inorganic fertilizer treatment shows better results compared to $75 \%$ inorganic fertilizer use. The results of the observation of the base diameter of the trunk can be seen in the Pictures and Tables, the following:

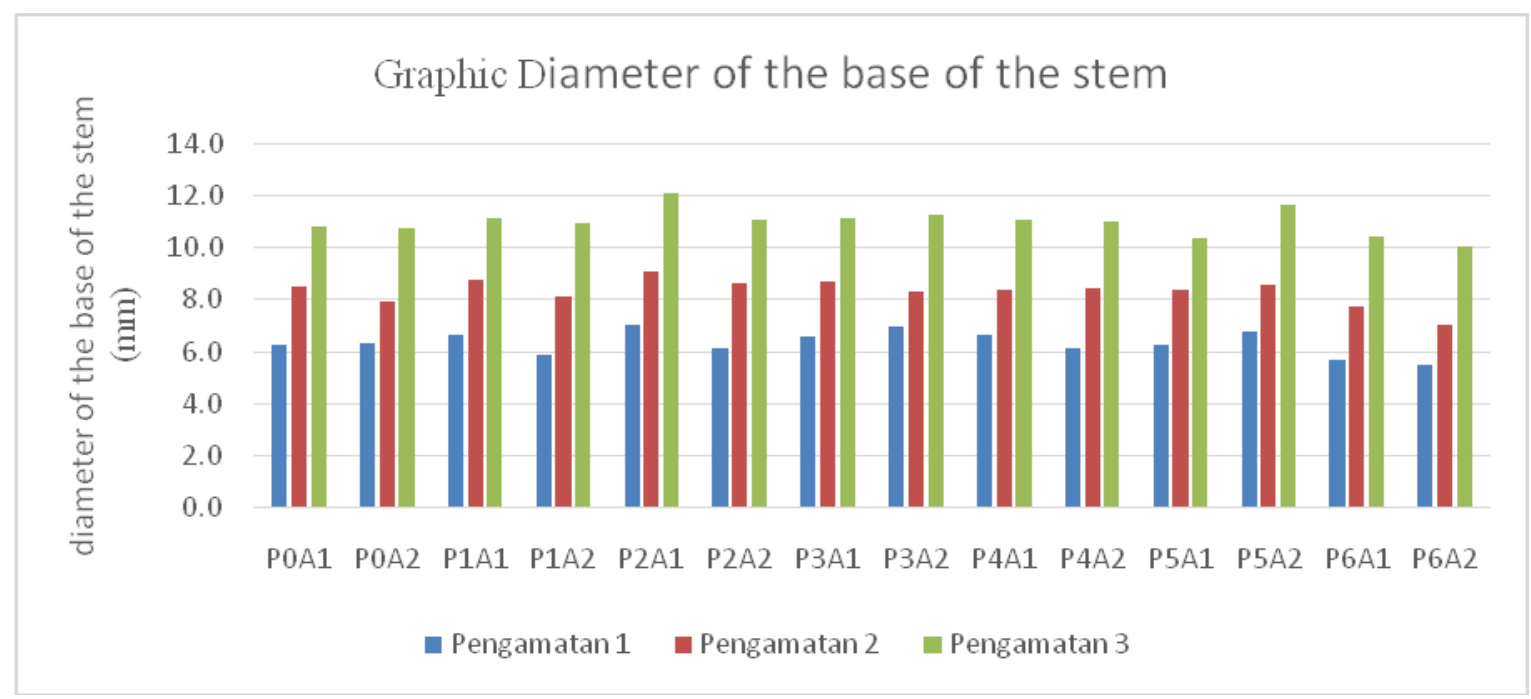

Figure 4. Graphic Base Diameter Observation Graph 4 - 6 WAP 
Table 3. Effect of Biofertilizer and Inorganic Fertilizer on Stem Base Diameter at 4 - 6 WAP

\begin{tabular}{|llll|}
\hline Treatment & \multicolumn{2}{l|}{ Observation $(\mathrm{mm})$} & \\
\cline { 2 - 4 } & $1(4 \mathrm{WAP})$ & $2(5 \mathrm{WAP})$ & $10.80 \mathrm{ab}$ \\
P0A1 & $6.25 \mathrm{abcd}$ & $8.50 \mathrm{a}$ & $11.11 \mathrm{ab}$ \\
P1A1 & $6.65 \mathrm{ab}$ & $8.75 \mathrm{a}$ & $12.09 \mathrm{a}$ \\
P2A1 & $7.05 \mathrm{a}$ & $9.08 \mathrm{a}$ & $11.11 \mathrm{ab}$ \\
P4A1 & $6.59 \mathrm{abc}$ & $8.69 \mathrm{a}$ & $11.09 \mathrm{ab}$ \\
P5A1 & $6.62 \mathrm{abc}$ & $8.38 \mathrm{a}$ & $10.33 \mathrm{~b}$ \\
P6A1 & $6.23 \mathrm{abcd}$ & $8.39 \mathrm{a}$ & $10.45 \mathrm{~b}$ \\
P0A2 & $5.66 \mathrm{~cd}$ & $7.76 \mathrm{ab}$ & $10.72 \mathrm{ab}$ \\
P1A2 & $6.34 \mathrm{abcd}$ & $7.94 \mathrm{ab}$ & $10.92 \mathrm{ab}$ \\
P2A2 & $5.90 \mathrm{bcd}$ & $8.09 \mathrm{ab}$ & $11.05 \mathrm{ab}$ \\
P3A2 & $6.12 \mathrm{abcd}$ & $8.61 \mathrm{a}$ & $11.23 \mathrm{ab}$ \\
P4A2 & $6.98 \mathrm{a}$ & $8.28 \mathrm{a}$ & $10.98 \mathrm{ab}$ \\
P5A2 & $6.15 \mathrm{abcd}$ & $8.46 \mathrm{a}$ & $11.61 \mathrm{ab}$ \\
P6A2 & $6.77 \mathrm{ab}$ & $8.59 \mathrm{a}$ & $10.04 \mathrm{~b}$ \\
\hline
\end{tabular}

Description : The numbers followed by the same letter in one column show no real difference on the Duncan test at a real rate of 0.05 .

\section{Plant Potency Change}

Observations of dry weight of plants (DWP) are carried out on 6 MST at the final vegetative period or the plant already shows signs of appearing flowers. The dry weight of the plant can be known after the plant is washed clean especially the root part and then dried ovenkan (700 $\mathrm{C}$ for 3 days). DWP observations showed the P2A1 treatment provided the best and real different results to control and 4 other treatments out of a total of 14 treatments, following the complete results of observations of dry weight of plants presented in Table 4.

Table 4. Effect of Biofertilizer and Inorganic Fertilizer on Plant Dry Weight at 6 WAP

Treatments Dry Weight Plants $(\mathrm{g})$




\begin{tabular}{|ll|}
\hline P0A1 & $5.197 \mathrm{c}$ \\
P1A1 & $10.363 \mathrm{ab}$ \\
P2A1 & $11.507 \mathrm{a}$ \\
P3A1 & $7.540 \mathrm{abc}$ \\
P4A1 & $9.073 \mathrm{abc}$ \\
P5A1 & $7.780 \mathrm{abc}$ \\
P6A1 & $5.277 \mathrm{c}$ \\
P0A2 & $5.723 \mathrm{bc}$ \\
P1A2 & $7.417 \mathrm{abc}$ \\
P2A2 & $6.287 \mathrm{bc}$ \\
P3A2 & $7.203 \mathrm{abc}$ \\
P4A2 & $6.017 \mathrm{bc}$ \\
P5A2 & $7.487 \mathrm{abc}$ \\
P6A2 & $7.117 \mathrm{abc}$ \\
\hline
\end{tabular}

Description : The numbers followed by the same letter in one column show no real difference on the Duncan test at a real rate of 0.05 .

P2A1 treatment is the 2nd isolate use treatment with $100 \%$ inorganic fertilizer application as recommended. This shows the data with the highest base diameter of the stem resulted in a high dry weight of the plant as well. Good stem base growth greatly helps increase plant weight so that plants can grow optimally.

Parameters of Paprika Plant Results

Harvesting of peppers starts at 10 MST - 16 MST with harvesting frequency every 2 weeks. The fruit's yield is weighed gradually according to the treatment and at the final harvest in the count of the volume and thickness of the peppers. The fruit observed is the most mature observed fruit, harvested on each unit of treatment plant and then the fruit is weighed according to the treatment on each replay. More data on the yield of paprika in the treatment of various biofertilizers and the level of inorganic fertilizer dose can be seen in the table, the following:

Table 5. The Effect of Biofertilizer and Inorganic Fertilizer On Paprika Results

\begin{tabular}{|lll}
\hline Treatments Harvest - (g) Total Results & Tol
\end{tabular}




\begin{tabular}{|llllll|} 
& & & & \\
& $1(10 \mathrm{WAP})$ & $2(12 \mathrm{WAP})$ & $3(14 \mathrm{WAP})$ & $4(16 \mathrm{WAP})$ & \\
\hline P0A1 & $400.00 \mathrm{~b}$ & $513.33 \mathrm{bc}$ & $513.33 \mathrm{c}$ & $604.33 \mathrm{a}$ & $2.031 \mathrm{c}$ \\
P1A1 & $510.00 \mathrm{ab}$ & $603.33 \mathrm{a}$ & $560.00 \mathrm{bc}$ & $602.67 \mathrm{a}$ & $2.276 \mathrm{ab}$ \\
P2A1 & $523.33 \mathrm{ab}$ & $596.00 \mathrm{a}$ & $553.33 \mathrm{bc}$ & $560.00 \mathrm{ab}$ & $2.233 \mathrm{abc}$ \\
P3A1 & $490.00 \mathrm{ab}$ & $556.67 \mathrm{abc}$ & $643.33 \mathrm{ab}$ & $498.67 \mathrm{ab}$ & $2.188 \mathrm{abc}$ \\
P4A1 & $523.33 \mathrm{ab}$ & $533.33 \mathrm{abc}$ & $550.00 \mathrm{bc}$ & $482.67 \mathrm{~b}$ & $2.089 \mathrm{bc}$ \\
P5A1 & $533.33 \mathrm{ab}$ & $513.33 \mathrm{bc}$ & $510.00 \mathrm{c}$ & $505.00 \mathrm{ab}$ & $2.061 \mathrm{bc}$ \\
P6A1 & $503.33 \mathrm{ab}$ & $533.33 \mathrm{abc}$ & $513.33 \mathrm{c}$ & $565.33 \mathrm{ab}$ & $2.115 \mathrm{bc}$ \\
P0A2 & $526.67 \mathrm{ab}$ & $560.00 \mathrm{abc}$ & $510.00 \mathrm{c}$ & $530.33 \mathrm{ab}$ & $2.127 \mathrm{abc}$ \\
P1A2 & $510.00 \mathrm{ab}$ & $593.33 \mathrm{a}$ & $536.67 \mathrm{c}$ & $493.67 \mathrm{~b}$ & $2.133 \mathrm{abc}$ \\
P2A2 & $446.67 \mathrm{ab}$ & $573.33 \mathrm{abc}$ & $543.33 \mathrm{bc}$ & $550.67 \mathrm{ab}$ & $2.114 \mathrm{bc}$ \\
P3A2 & $490.00 \mathrm{ab}$ & $503.33 \mathrm{c}$ & $553.33 \mathrm{bc}$ & $566.00 \mathrm{ab}$ & $2.113 \mathrm{bc}$ \\
P4A2 & $610.00 \mathrm{a}$ & $583.33 \mathrm{ab}$ & $590.00 \mathrm{abc}$ & $568.67 \mathrm{ab}$ & $2.352 \mathrm{a}$ \\
P5A2 & $506.67 \mathrm{ab}$ & $570.00 \mathrm{abc}$ & $670.00 \mathrm{a}$ & $543.33 \mathrm{ab}$ & $2.290 \mathrm{ab}$ \\
P6A2 & $463.33 \mathrm{ab}$ & $543.33 \mathrm{abc}$ & $523.33 \mathrm{c}$ & $547.00 \mathrm{ab}$ & $2.077 \mathrm{bc}$ \\
\hline
\end{tabular}

Description : The numbers followed by the same letter in one column show no real difference on the Duncan test at a real rate of 0.05 .

Observation of the volume and thickness of fruit meat is carried out at the last harvest to know the quality of the peppers. The volume and thickness of the fruit is observed in each fruit of each treatment. The fruit thickness observation technique can be seen in Figure 5 and the data of the observation of the volume and thickness of the fruit can be seen in the following table:

Table 6. Effect of Biofertilizer and Inorganic Fertilizer on The Volume and Thickness of Paprika fruit in 16 WAP.

\begin{tabular}{|lll|}
\hline Treatments & \multicolumn{2}{l|}{ Parameter Quality of Fruits } \\
\cline { 2 - 3 } & Volume $(\mathrm{ml})$ & Thickness $(\mathrm{mm})$ \\
\hline P0A1 & $341.11 \mathrm{a}$ & $7.11 \mathrm{abc}$ \\
P1A1 & $338.89 \mathrm{a}$ & $7.47 \mathrm{a}$ \\
\hline
\end{tabular}


International Journal of Agriculture, Environment and Bioresearch

Vol. 6, No. 01; 2021

ISSN: $2456-8643$

\begin{tabular}{|lll|}
\hline P2A1 & $313.33 \mathrm{ab}$ & $7.24 \mathrm{abc}$ \\
P3A1 & $284.44 \mathrm{ab}$ & $6.45 \mathrm{bc}$ \\
P4A1 & $267.78 \mathrm{~b}$ & $6.38 \mathrm{c}$ \\
P5A1 & $291.11 \mathrm{ab}$ & $6.79 \mathrm{abc}$ \\
P6A1 & $314.44 \mathrm{ab}$ & $6.96 \mathrm{abc}$ \\
P0A2 & $306.67 \mathrm{ab}$ & $7.13 \mathrm{abc}$ \\
P1A2 & $282.22 \mathrm{ab}$ & $6.70 \mathrm{abc}$ \\
P2A2 & $317.78 \mathrm{ab}$ & $7.35 \mathrm{ab}$ \\
P3A2 & $324.44 \mathrm{ab}$ & $6.93 \mathrm{abc}$ \\
P4A2 & $317.78 \mathrm{ab}$ & $7.27 \mathrm{abc}$ \\
P5A2 & $301.11 \mathrm{ab}$ & $7.11 \mathrm{abc}$ \\
P6A2 & $313.33 \mathrm{ab}$ & $7.32 \mathrm{ab}$ \\
\hline
\end{tabular}

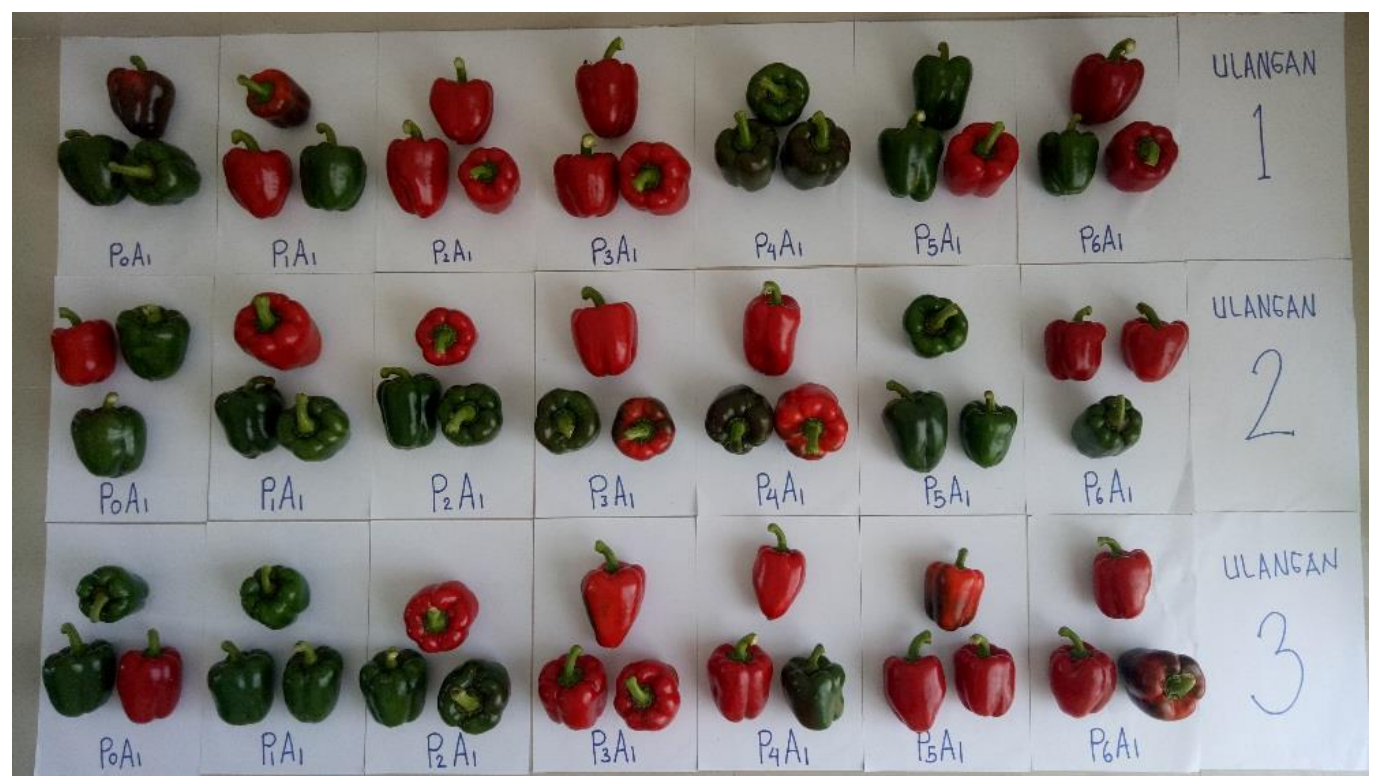

Figure 5. Crop 3 (14 WAP) Use of Various Biofertilizers with 100\% Inorganic Fertilizer Dose 
Vol. 6, No. 01; 2021

ISSN: $2456-8643$

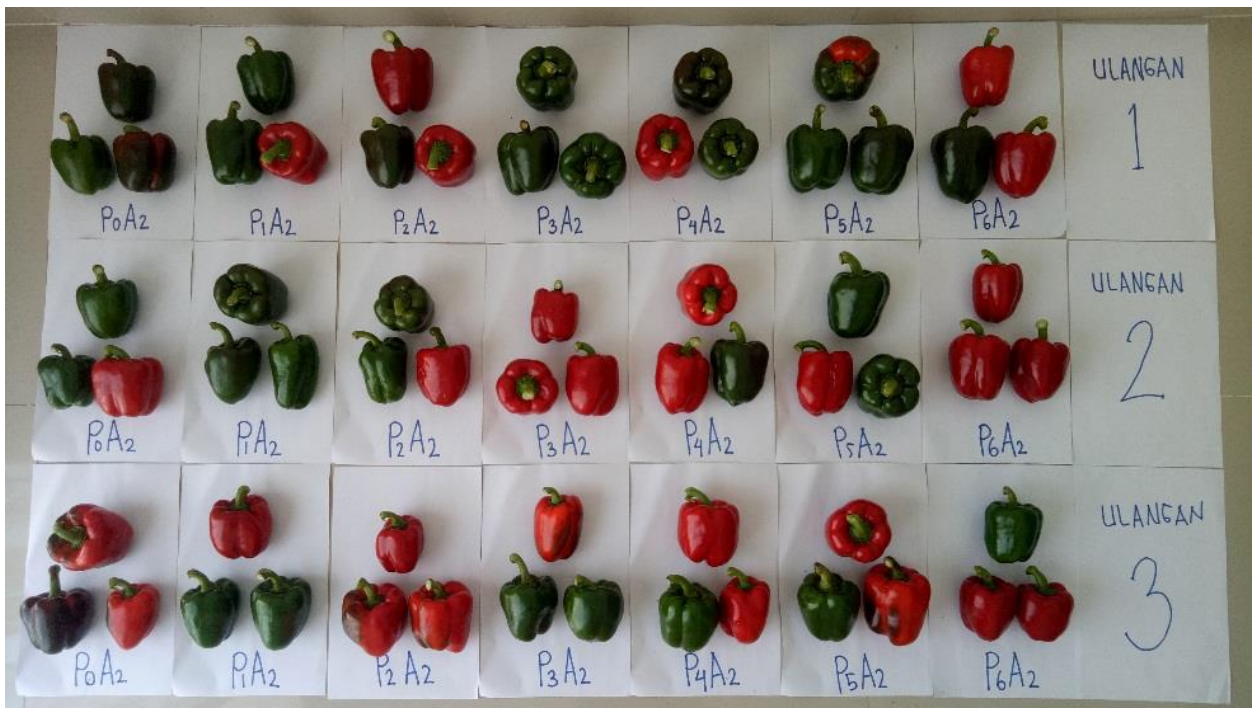

Figure 6. Crop 3 (14 MST) Use of Various Biofertilizers with Inorganic Fertilizer Dose 75\%

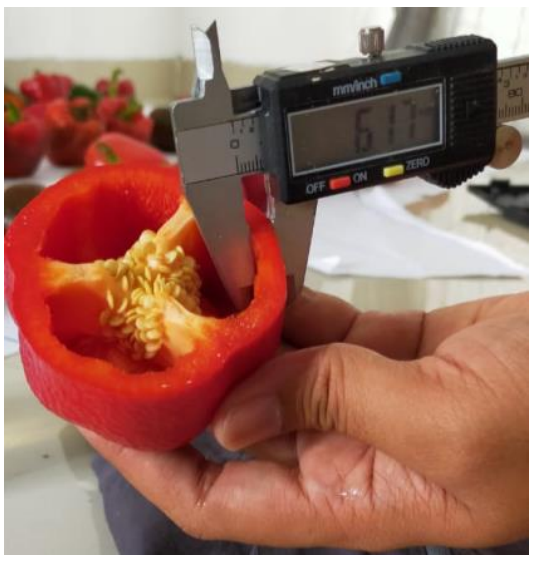

Figure 7. Thick Observations of Paprika 
Vol. 6, No. 01; 2021

ISSN: $2456-8643$

\section{DISCUSSION}

The application of 3 isolates from MOL and its consortium with the comparison of 2 biological fertilizers as well as the application of 2 levels of an-organic fertilizer dose does not significantly affect the real difference on all observations. Paprika plant growth observation data shows the height and base diameter of the stem results best demonstrated by the treatment of consortium biofertilizer and isolate 1 (Bacillus cereus 1) with a combination of $100 \%$ inorganic fertilizer dose. This gives an overview of the still highly dependent growth of plants with the use of inorganic fertilizers especially on cultivation of crops with non-soil media. Rahmawati et al, 2018 states nutrition for hydroponic paprika plants has an important role in plant growth because it is the main food source for plants. The use of organic nutrients should be combined with inorganic nutrients to complement each other because it can have an excellent influence on plant growth and yield (Lestari, 2009).

Observation of crop yields by harvesting peppers on 10 MST, describing the growth of paprika crops is quite normal as cultivated farmers grow peppers. The harvest of peppers in this study was done 4 times with a duration every 2 weeks, this is done so that the fruits of the peppers when harvested are already in optimal form. The highest total yield of peppers is indicated by the treatment of the use of consortium biofertilizer with a dose of inorganic fertilizer $75 \%$, this indicates the growth of paprika crops can continue to increase until the final generative period. Plants can grow optimally if the factors that affect them are met, those factors include the availability of water, light, nutrients and planting media that support root growth. Hartus (2002) that the key to success in hydroponic efforts is nutrient solutions, which among others must meet the requirements of the concentration of the solution and the proper dose of nutrients for each type of plant as well as the volume given to suit the needs of the plant. The use of inorganic fertilizer with a dose of $75 \%$ in liquid form is also very helpful absorption by paprika plants. The advantage of using liquid fertilizer is that it is quickly and easily absorbed by plants, so it is suitable for plants with short life cycles (annual plants), in addition to its more complete nutrient content both macro and micro (Phallus and Marsono, 2000).

The shape and color of the fruit (Figs 5 and 6) is also perfectly dominant with red and the fruit shape resembles a bell. The thickness of the fruit (Figure 7) shows a fairly thick result (>6 mm) so that the taste and texture of the fruit is crisp with a large dominant fruit volume $(>300 \mathrm{ml})$ this indicates the fruit fruit can already enter grade A (best) and can supply supermarket and export markets. According to Resh (2004) hydroponic cultivation has several advantages compared to cultivation in the soil, i.e. plant nutrients are more homogeneous and controllable, not limited by the availability of nutrients in the soil, do not require soil processing, fertilizer use is more efficient, planting media is more permanent because it can be used for a long period of time, and disease pests tend to be reduced. With the substrate hydroponic system used in pepper cultivation research, plant nutrients can be more maintained even more in the use of biological fertilizers. Sutedjo(2008), said that a common characteristic of organic fertilizer is the availability of slow nutrients, whereby nutrients derived from organic matter require microb activities to change from the form of organic complex bonds that can not be utilized by plants into simple forms of organic and inorganic compounds that can be absorbed by plants. Paprika plants need organic matter to get energy for their growth. According to Salisbury and Ross (1995), if the plant lacks any of the required elements then the plant will not be able to complete its life cycle because it plays a direct role in plant life and its position cannot be replaced by other elements. 
Vol. 6, No. 01; 2021

ISSN: $2456-8643$

\section{CONCLUSION}

The highest plant height $(67,927 \mathrm{~cm})$ is indicated by the consortium's biofertilizer treatment with an inorganic fertilizer dose of $100 \%$ (P4A1) while the base diameter of the largest stem $(12.09 \mathrm{~cm})$ is indicated by the treatment of bacillus cer isolate biofertilizer the origin of MOL rabbit manure with a dose of inorganic fertilizer $100 \%$ (P2A1) this remains consistent with the results of dry weight of plants with the best results shown by the treatment of biofertilizer isolate Bacillus Cereus with a dose of inorganic fertilizer $100 \%$ (P2A1).

The highest total yield of paprika $(2352 \mathrm{~g})$ is indicated by the treatment of consortium biofertilizer with $75 \%$ inorganic fertilizer (P4A2).

The quality of the fruit observed in the harvest of 16 MST shows for the highest fruit volume $(341.11 \mathrm{ml})$ indicated by without the use of biological fertilizer with a dose of inorganic fertilizer $100 \%$ (P0A1) and the thickness of the highest fruit $(7.47 \mathrm{~mm})$ indicated by the treatment of bacillus cereus insulate biofertilizer from MOL bamboo root with a dose of inorganic fertilizer $100 \%$ (P1A1).

\section{REFERENCE}

Hartus, T. 2002. Cheap Hydroponic Gardening. Self-Help Spreader, Jakarta.

Lancaster J. 2009. Paprika : A Scoping Study of the Market and Value Chain. Sidney (AU) :Rural Industries Research and Development Corporation.

Sustainable, A. P. 2009.Sustainable Agricultural Development Through Inorganic Fertilizer Subtitution with Organic Fertilizer. ArgonomiJournal.13(1):38-44.

Phallus, P. and Marsono, 2000. Instructions for Use of Fertilizer. Self-Help Spreader, Jakarta.

Data Center and Agricultural Information System. 2015. Agricultural Commodities Outlook Sub Horticultural Sector: Chili Peppers. Jakarta (ID) : Secretariat General of the Ministry of Agriculture.

Prihmantoro H, Indriyani YH. 2003. Hydroponic and Nonhidroponic Peppers. Jakarta : PT. SelfHelp Spreader.

Rahmawati, F., Wicaksono, KP.,Aini, N. 2018. The Effect of Fermentation of Rabbit Urine And Fermentation of Paitan On The Growth And Yield of Paprika Crops (Capsicum AnnuumvarGrossum) With Substrate Hydroponic System. Journal of Plant ProductionVol. 6 No. 2, February 2018: 194-202ISSN: 2527-8452

Resh, H.M. 2004. Hydroponic Food Production: A Definitive Guidebook of Soiless FoodGrowing Methods. 6th Ed. NewconceptPr, Inc.New Jersey.US.

Salisbury,F.B., C.W. Ross. 1995. Basic Plant Physiology Volume I. ITB Publisher. Bandung. Sesanti RN, Sismanto. 2016. Growth and results of pakchoi (Brasicarapa L.) in two hydroponic systems and four types of nutrients. Journal of Kelitbangan.4(1) : 1-9.

Sutedjo, M.M. 2008. Fertilizer and Fertilization. RinekaCipta.Jakarta. 